\title{
On sinuses and vortices
}

\author{
Tirone E. David, MD
}

\footnotetext{
From the Division of Cardiac Surgery, Peter Munk Cardiac Centre at Toronto General Hospital and the University of Toronto, Toronto, Ontario, Canada.

Disclosures: Author has nothing to disclose with regard to commercial support.

Received for publication May 13, 2017; accepted for publication May 18, 2017; available ahead of print June 13 , 2017.

Address for reprints: Tirone E. David, MD, 200 Elizabeth St 4N453, Toronto, Ontario M5G 2C4, Canada (E-mail: tirone.david@uhn.ca).

J Thorac Cardiovasc Surg 2017;154:791-3

$0022-5223 / \$ 36.00$

Copyright (c) 2017 by The American Association for Thoracic Surgery

http://dx.doi.org/10.1016/j.jtcvs.2017.05.056
}

Innovative operative procedures often arise from past experiences and long-term observations of established operations. The development of aortic valve-sparing operations was a stepwise, evolutionary process that occurred after we learned practical lessons of functional anatomy of the aortic valve, mostly by performing aortic valve repair and replacement with stentless biologic valves implanted in the subcoronary position. Postoperative assessment of valve function after these operations made us understand the interplays among the various components of the aortic root that allow unimpeded laminar flow during systole and prevent regurgitation of blood during diastole.

When my group first described reimplantation of the aortic valve into a tubular Dacron polyester fabric graft, ${ }^{1}$ we were told repeatedly that the operation would fail after a few years because we had placed the aortic valve into a rigid and cylindric structure, a physiologically unsound operation. During the first few years of our experience, we were very careful; we operated only on 19 patients with aortic root aneurysm and normal cusps, and we carefully monitored aortic valve function during the followup. ${ }^{1}$ As we gained confidence in this operation, we began to include patients with elongated cusps with prolapse. ${ }^{2}$ We continued to expand its use and included flimsy cusps by weaving a double layer of a fine Gore-Tex suture (W. L. Gore \& Associates, Medical Products Division, Flagstaff, Ariz) along the free margins to save the valve in young patients with aortic root aneurysms. ${ }^{3}$ We also made several technical modifications to the 2 basic types of aortic valve sparing operations, as described by D. Craig Miller as David I, II, III, IV, and V. ${ }^{4}$ After doing these operations for more than a quarter of century and carefully monitoring our patients' aortic valve function, we now have data that reimplantation of the aortic valve into a straight tubular Dacron polyester fabric graft is a durable operation. ${ }^{5}$ In our last report, we had 32 patients at risk at 15 years. Freedom from aortic insufficiency greater than mild was $92.3 \% \pm 2.8 \%$, and freedom from reoperation on the aortic valve was $96.9 \% \pm 1.3 \%$. These results are superior to our results with Bentall operations with mechanical or tissue

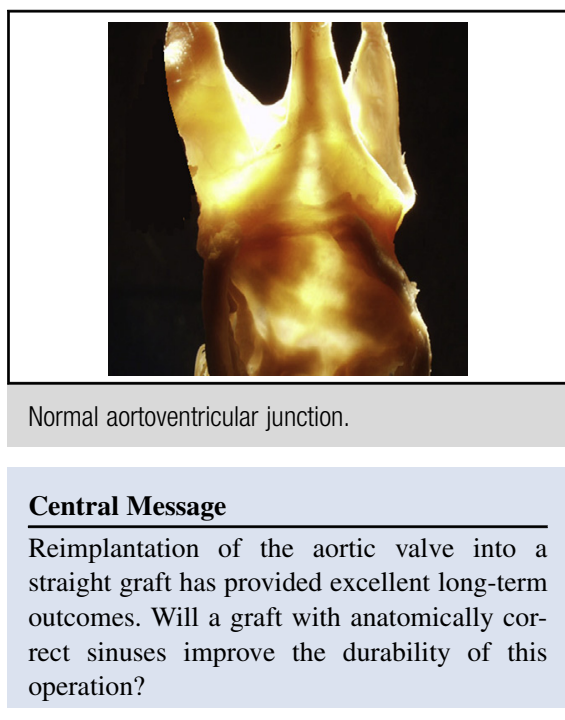

See Article page 794.

valves. ${ }^{6}$ Thus, as unphysiologic as this operation may be, clinical experience far exceeds the scientific basis of aortic valve-sparing operations.

In this issue of the Journal, Oechtering and colleagues ${ }^{7}$ have an article entitled, "Malrotated Sinus Vortices in Straight Graft Valve-Sparing Aortic Root Treatment: A Matter of Concern?" in which they demonstrated grossly abnormal flow across the aortic root in 3 patients who had the aortic valve reimplanted into a straight tubular graft. The 4-dimensional magnetic resonance imaging color images are quite spectacular and demonstrate the wonders of modern technology. The same group of investigators had published a similar study on patients who had undergone reimplantation of the aortic valve into a graft with anatomically correct sinuses (Uni-Graft W SINUS; Braun, Melsungen, Germany) and showed fairly normal flows, with nearly physiologic sinus vortex formation and transvalvular pressure gradients.

Dacron polyester fabric grafts with aortic sinuses have been commercially available for many years, but we have not used them because the shape of the sinuses is incorrect. ${ }^{9}$ As illustrated in Figure 1, these grafts have spherical sinuses. The normal aortoventricular junction evolves within a cylinder, as shown in Figure 2. Grafts with spherical sinuses therefore deform the aortoventricular junction after reimplantation of the aortic valve. In addition, the height of the spherical portion of these grafts does not coincide with patients' aortic root height, creating another technical and anatomic problem during the 


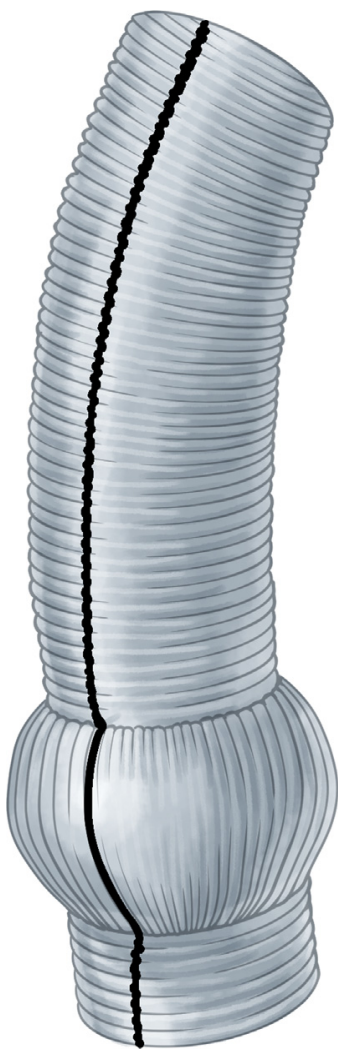

FIGURE 1. Sketch of a Dacron polyester fabric graft with spherical sinuses. Reproduced with permission.?

operation. Figure 3 shows a sketch of an anatomically correct Dacron polyester fabric graft with sinuses (Uni-Graft W SINUS), which is now being used clinically. ${ }^{8}$ The Uni-

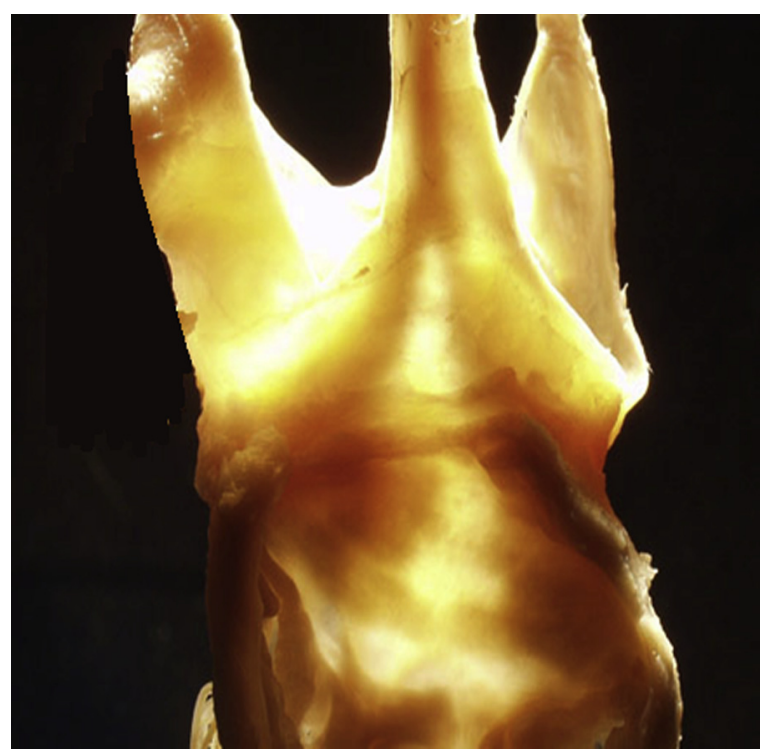

FIGURE 2. Photograph of a human aortic root without sinuses. Note that the aortic annulus evolves within a cylinder. (Courtesy of Muresian Horia, $\mathrm{MD}, \mathrm{PhD}$, Bucharest, Romania.)

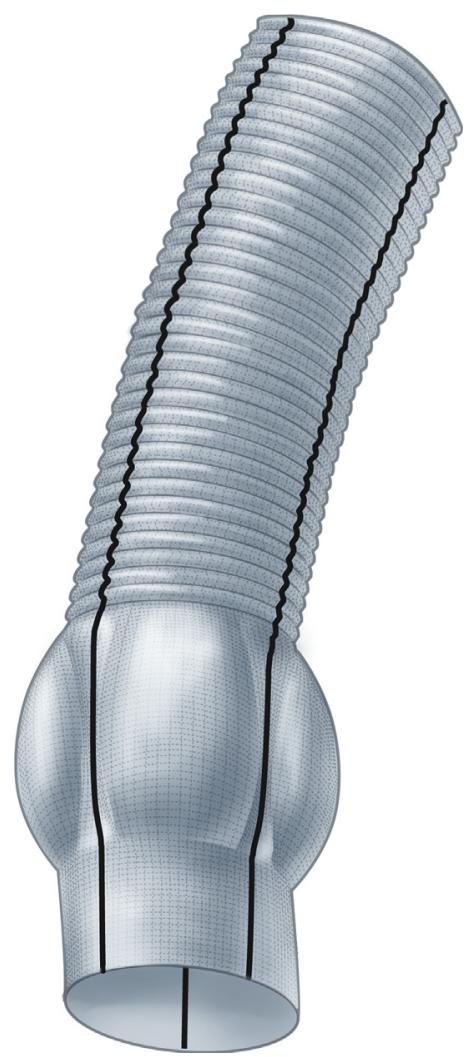

FIGURE 3. Sketch of a Dacron polyester fabric graft with anatomically correct sinuses. Reproduced with permission.?

Graft may represent the next level of evolution of reimplantation of the aortic valve to treat patients with aortic root aneurysm. The beneficial effect of this anatomically correct Dacron polyester fabric graft on durability of reimplantation of the aortic valve will be difficult to establish, however, because tubular grafts already provide excellent long-term results. ${ }^{5}$ Moreover, reimplantation of the aortic valve is a technically difficult operation, and the outcome is probably more dependent on the surgeon's ability to restore a functionally reasonable anatomic arrangement among the various components of the aortic root than on the type of graft used. Kari and colleagues ${ }^{10}$ examined the issue of residual and progressive aortic insufficiency in 1015 patients who underwent aortic valve-sparing operations in 4 cardiac units in Germany, including the one in which the study of Oechtering and colleagues ${ }^{7}$ was conducted. A quarter of the patients were excluded because of inadequate information on aortic valve function early or late after surgery. Postoperative echocardiograms of 764 patients (91\% with David I operations and 9\% with David II operations) showed that $29 \%$ of patients left the hospital with mild aortic insufficiency. After a mean follow-up of 4.1 years, $30 \%$ had progressive aortic insufficiency, which led to aortic valve replacement in $10 \%$ of the of patients by 8 years. The authors concluded that 
"residual and progressive aortic insufficiency are considerable after aortic valve sparing operations." ${ }^{10}$ My interpretation is that aortic valve-sparing operations are not easily reproducible. Selection of patients, meticulous and extensive external dissection of the aortic root to a level beneath the nadir of the aortic annulus, graft sizing, fixation of the graft on the left ventricular outflow tract, fixation of the commissures and aortic annulus in the graft, and adjustment of the coaptation height of the aortic cusps are all important steps in this operation. An anatomically correct Dacron polyester fabric graft is scientifically sounder than a tubular graft, but the aortic valve will fail if the operation is not correctly performed.

\section{References}

1. David TE, Feindel CM, Bos J. Repair of the aortic valve in patients with aortic insufficiency and aortic root aneurysm. J Thorac Cardiovasc Surg. 1995;109: 345-51; discussion 351-2.

2. David TE, Armstrong S, Ivanov J, Feindel CM, Omran A, Webb G. Results of aortic valve-sparing operations. J Thorac Cardiovasc Surg. 2001;122:39-46.
3. David TE, Armstrong S. Aortic cusp repair with Gore-Tex sutures during aortic valve-sparing operations. J Thorac Cardiovasc Surg. 2009;139: 1340-2.

4. Miller DC. Valve-sparing aortic root replacement in patients with the Marfan syndrome. J Thorac Cardiovasc Surg. 2003;125:773-8.

5. David TE, David CM, Feindel CM, Manlhiot C. Reimplantation of the aortic valve at 20 years. J Thorac Cardiovasc Surg. 2017;153:232-8.

6. Ouzounian M, Rao V, Manlhiot C, Abraham N, David C, Feindel CM, et al. Valve-sparing root replacement compared with composite valve graf procedures in patients with aortic root dilation. J Am Coll Cardiol. 2016; 68:1838-47.

7. Oechtering TH, Frydrychowicz A, Sievers HH. Malrotated sinus vortices in straight graft valve-sparing aortic root treatment: a matter of concern? J Thorac Cardiovasc Surg. 2017;154:794-7.

8. Oechtering TH, Hons CF, Sieren M, Hunold P, Hennemuth A, Huellebrand M, et al. Time-resolved 3-dimensional magnetic resonance phase contrast imaging (4D flow MRI) analysis of hemodynamics in valve sparing aortic root repair with an anatomically shaped sinus prosthesis. J Thorac Cardiovasc Surg. 2016;152:418-27.e1

9. David TE. Aortic valve sparing in different aortic valve and aortic root conditions. J Am Coll Cardiol. 2016;68:654-64.

10. Kari FA, Doll KN, Hemmer W, Liebrich M, Sievers HH, Richardt D, et al. Residual and progressive aortic regurgitation after valve-sparing root replacement: a propensity-matched multi-institutional analysis in 764 patients. Ann Thorac Surg. 2016;101:1500-6.

Access to The Journal of Thoracic and Cardiovascular Surgery Online is reserved for print subscribers!

Full-text access to The Journal of Thoracic and Cardiovascular Surgery Online is available for all print subscribers. To activate your individual online subscription, please visit The Journal of Thoracic and Cardiovascular Surgery Online, point your browser to http://www.mosby.com/jtcvs, follow the prompts to activate your online access, and follow the instructions. To activate your account, you will need your subscriber account number, which you can find on your mailing label (note: the number of digits in your subscriber account number varies from 6 to 10 ). See the example below in which the subscriber account number has been circled:

\section{Sample mailing label}

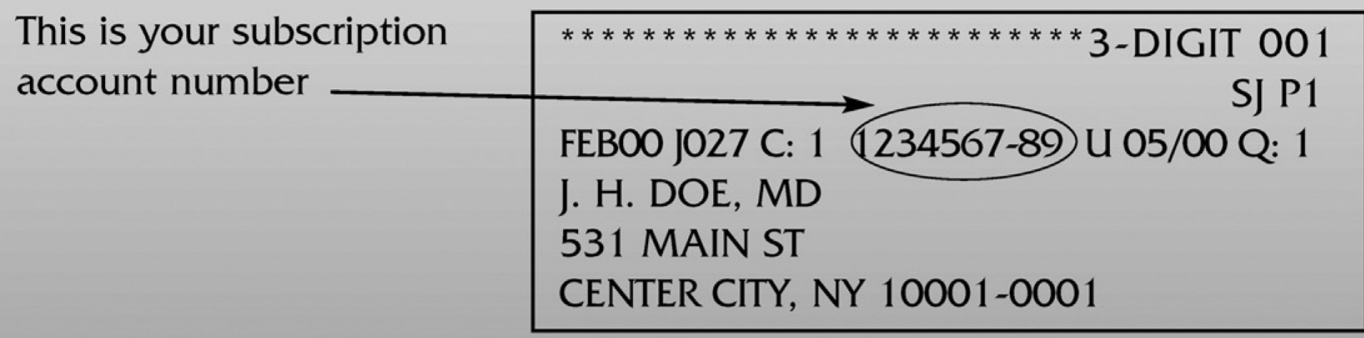

Personal subscriptions to The Journal of Thoracic and Cardiovascular Surgery Online are for individual use only and may not be transferred. Use of The Journal of Thoracic and Cardiovascular Surgery Online is subject to agreement to the terms and conditions as indicated online. 